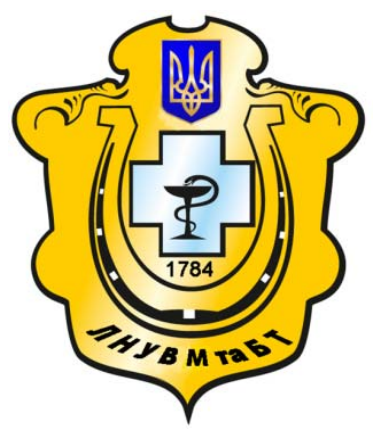

Науковий вісник Львівського національного університету ветеринарної медицини та біотехнологій імені С.3. Гжицького

Scientific Messenger of Lviv National University of Veterinary Medicine and Biotechnologies named after S.Z. Gzhytskyj

doi:10.15421/nvlvet6816

ISSN 2413-5550 print

ISSN 2518-1327 online

$\underline{\text { http://nvlvet.com.ua/ }}$

УДК 664.38

\title{
Дослідження дисперсності напою 3 волоського горіха
}

\author{
Ю.Ю. Савчук ${ }^{1}$, С.І. Усатюк ${ }^{1}$, О.П. Янчик ${ }^{2}$ \\ yura.savchuk.91@mail.ru
}

\author{
${ }^{1}$ Національний університет харчових технологій, вул. Володимирська, 68, м. Київ, 01601, Украйна \\ Вінницький торговельно-економічний інститут Київського національного торговельно-економічного \\ університету, вул. Соборна, 70, м. Вінниия, 21050 Украӥна
}

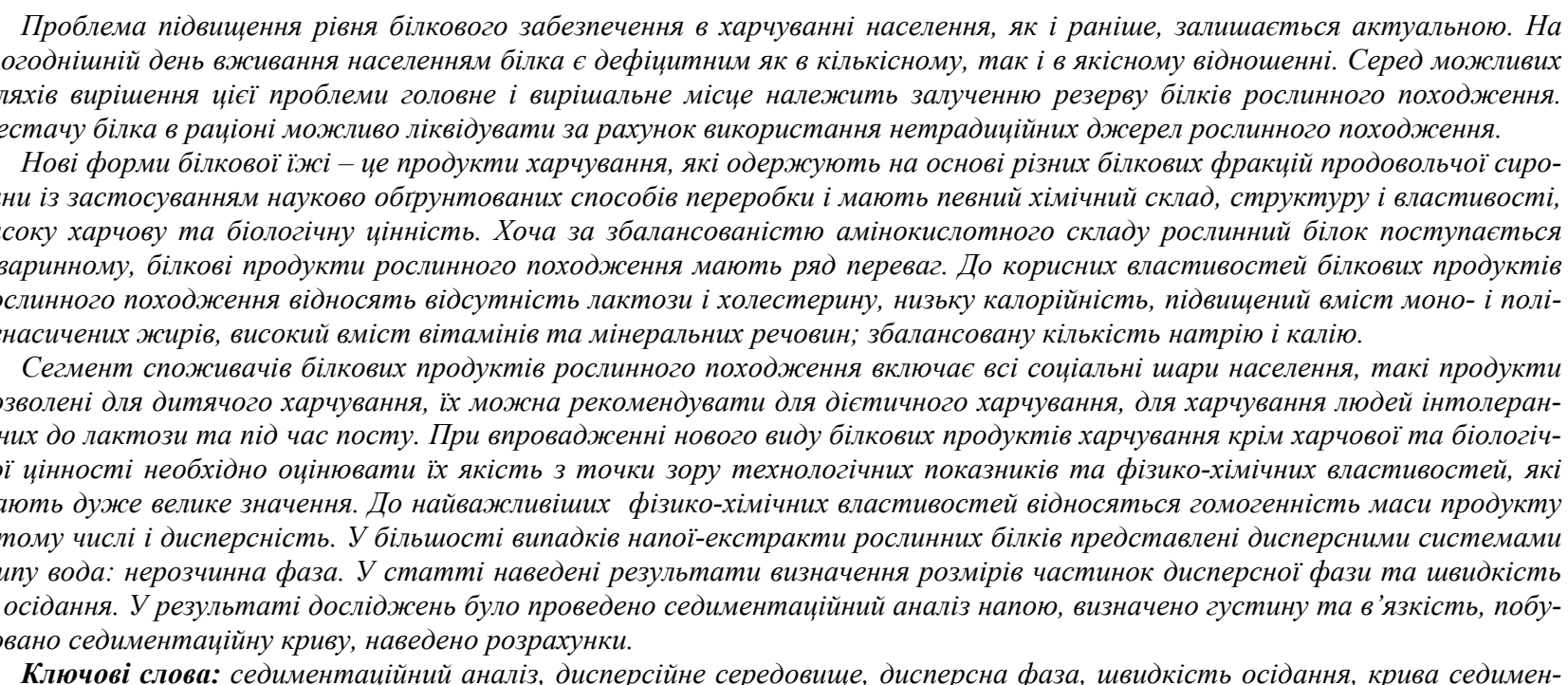

Ключові слова: седиментаиійний аналіз, дисперсійне середовище,
ації, радіус частинки, фракційний склад, напій з волоського горіха.

\section{Исследование дисперсности напитка с грецкого ореха}

\author{
Ю.Ю. Савчук ${ }^{1}$, С.И. Усатюк ${ }^{1}$, Е.П. Янчик ${ }^{2}$ \\ yura.savchuk.91@mail.ru
}

Нацииональный университет пищевых технологий, ул. Владимирская, 68, г. Киев, 01601, Украина Винницкий торгово-экономический институт Киевского начионального торгово-экономического университета, ул. Соборная, 70, Винница, 21050, Украина

Проблема повышения уровня белкового обеспечения в питании населения по-прежнему остается актуальной. На сегодняшний день употребления населением белка является дефицитным как в количественном, так и в качественном отношении. Среди возможных путей решения этой проблемы главное и решающее место принадлежит привлечению резерва белков растительного происхождения. Недостаток белка в рационе может быть ликвидирован за счет использования нетрадиционных источников растительного происхождения.

Citation:

Savchuk, Y.Y., Usatiuk, S.I., Yanchyk, O.P. (2016). Dispersion research of drink from walnut. Scientific Messenger LNUVMBT named after S.Z. Gzhytskyj, 18, 2(68), 83-86 
Новые формы белковой пищи - это продукты питания, которые получают на основе различных белковых фракиий продовольственного сырья с применением научно обоснованных способов переработки и имеют определенныи химический состав, структуру и свойства, высокую пищевую и биологическую ценность.

Хотя за сбалансированностью аминокислотного состава растительный белок уступает животному, белковые продукты растительного происхождения имеют ряд преимуществ. К полезным свойствам белковых продуктов растительного происхождения относят отсутствие лактозы и холестерина, низкую калорийность, повышенное содержание моно- и полиненасыщенных жиров, высокое содержание витаминов и минеральных веществ; сбалансированное количество натрия и калия

Сегмент потребителей белковых продуктов растительного происхождения включает все социильнье слои населения, такие продукты разрешены для детского питания, их можно рекомендовать для диетического питания, для питания людей интолерантных клактозе и во время поста.

При внедрении нового вида белковых продуктов питания кроме пищевой и биологической ценности необходимо оценивать их качество с точки зрения технологических показателей и физико-химичних свойств, которые имеют очень большое значение. К наиболее важным физико-химичних свойствам относятся гомогенность массы продукта в том числе и дисперсность. В больиинстве случаев напитки-экстракты растительных белков представлены дисперсными системами типа вода: нерастворимая фаза.

В статье приведены результаты определения размеров частиц дисперсной фазы и скорость их оседания. В результате исследований было проведено седиментационно анализ напитка, определены плотность и вязкость, построено седиментаичионую кривую, приведень расчетьл.

Ключевые слова: седиментационно анализ, дисперсионная среда, дисперсная фаза, скорость оседания, кривая седиментации, радиус частицьы, фракционный состав, напиток из грецкого ореха.

\title{
Dispersion research of drink from walnut
}

\author{
Y.Y. Savchuk ${ }^{1}$, S.I. Usatiuk ${ }^{1}$, O.P. Yanchyk ${ }^{2}$ \\ yura.savchuk.91@mail.ru
}

\author{
${ }^{1}$ National University of Food Technologies, Volodymyrska Str., 68, Kyiv, 01601, Ukraine \\ ${ }^{2}$ Vinnitsa Trade and Economic Institute of Kyiv National University of Trade and Economics, \\ Cathedral Str., 70, Vinnitsa, 21050, Ukraine
}

The problem o increasing of level of proteinaceous providing in food of the population still remains actual. The current level of protein consumption by the population is deficient as in quantitative, and in a qualitative sense. Among the possible solutions to this problem, the most important and decisive place belongs to attract reserve of plant proteins. It is possible to liquidate a lack of protein in a diet due to use of nonconventional sources of plant protein.

New forms of proteinaceous food are products, which receive based on various proteinaceous fractions of food staples using evidence-based methods of conversion and have a certain chemical composition, structure and properties, high nutrition and biological value.

Although the balance of amino-acid structure plant protein yields to an animal, proteinaceous products of plant origin have a number of advantages. By the useful properties of plant protein products include lack of lactose and cholesterol, low caloric content, the increased content of mono - and polyunsaturated fats, the high content of vitamins and mineral substances; balanced amount of sodium and potassium.

The segment of consumers of proteinaceous products of plant origin includes all social groups of the population, such products are resolved for baby food, they can be recommended for dietary food, for food of people with intolerance of lactose and during a post. In case of implementation of a new type of proteinaceous food except nutritional and biological value, it is necessary to estimate their quality from the point of view of technological indicators and physical-chemical properties, which are very important. The most important physical-chemical properties include homogeneity of mass of a product including dispersion.

In most cases, drinks-extracts of plant proteins are dispersed systems, as water: insoluble phase.

Results of definitions the sizes of particles of a dispersed phase and speed of their subsidence are given in article. As a result of researches it has been carried out sedimentation analysis of drink, determined the density and viscosity, constructed a sedimentation curve and shows calculations.

Key words: sedimentary analysis, dispersive environment, dispersed phase, sedimentation speed, sedimentation curve, particle radius, fractional composition, a drink from walnut.

\section{Вступ}

За останні кілька років в світі чітко окреслилася тенденція зростання популярності здорового харчування. Споживачі все частіше зупиняють свій вибір на продукції, основними характеристиками якої $\epsilon$ не тільки привабливий зовнішній вигляд і приємний смак, але й натуральність компонентів і корисність.
Актуальним напрямком у харчовій промисловості $\epsilon$ розроблення білкових продуктів з рослинної сировини. Продукти 3 вмістом білків рослинного походження корисні для здоров'я і низькокалорійні. Забезпечення якості білкових продуктів з рослинної сировини - одне із завдань спеціалістів харчової галузі.

Напої рослинного походження, як правило, є складними дисперсними системами, які містять нерозчинну фазу. Оскільки нерозчинні у дисперсійному сере- 
довищі компоненти напою мають властивість осідати, виникає проблема з зовнішнім виглядом напою. Швидкість осідання дисперсної фази, а отже і розшарування напою залежить від розміру нерозчинних частинок (Mchedlov-Petrosjan et al., 2004; Mank et al., 2008; Poperechnyj and Kornijchuk, 2009; Peshuk and Nosenko, 2011).

Метою досліджень є визначення розмірів частинок дисперсної фази та швидкість їх осідання. Для досягнення поставленої мети були поставлені наступні завдання: провести седиментаційний аналіз напою, визначити густину та в'язкість, виконати розрахунки, побудувати криву седиментації, визначити у відсотковому співвідношенні фракційний склад осаду напою.

\section{Матеріал і методи досліджень}

Дисперсійний аналіз - це розділ колоїдної хімії, у якому вивчають методи визначення розмірів часток $\mathrm{i}$ розділення дисперсних систем на фракції за розмірами.

У нестійких дисперсних системах з частками від $10^{-4}$ до $10^{-6}$ м для визначення їх розмірів використовують метод седиментаційного аналізу, заснований на визначенні швидкості осідання (седиментації) часток у рідкому середовищі.

Густину дисперсійного середовища визначали ареометром згідно ДСТУ ГОСТ 28947:2009 Ареометри скляні. В'язкість визначали на ротаційному віскозиметрі типу Реотест -2 .

\section{Результати та їх обговорення}

Об'єктом дослідження є напій з ядер волоського горіха, який є складною дисперсною системою, оскільки містить три взаємо нерозчинні фази. Дисперсійним середовищем виступає водна фаза, другою фазою $\epsilon$ нерозчинні у воді білки та високо молекулярні сполуки (ВМС), третьою - жирова фаза.

Напій був отриманий шляхом попереднього замочування горіхів, їх подрібнення та подальшого екстрагування сольовим розчином концентрацією 1,0\%.

Для проведення седиментаційного аналізу напою використовували торзійні ваги типу ВТ з шалькою, яка була занурена в напій. Періодично зважували осад на шальці до встановлення постійної маси. Результати вимірювань представлені на рис. 1

Швидкість осідання часточок отримали із закону Стокса, що пов'язує швидкості осідання кулеподібної частки із силою в'язкого опору, який виникає при русі частки радіусом $\mathrm{r}$.

$$
f_{l}=6 \cdot \pi \cdot r \cdot \eta \cdot U
$$

де $f_{l}$ - сила в'язкого опору;

$\eta$ - коефіцієнт в'язкості рідини (дисперсійного середовища);

$r$ - радіус частинки, що осідає;

$U$ - швидкість частинки, що осідає.

Силу тяжіння $f_{2} 3$ якою осідають частинки визначали за формулою:

$$
f_{2}=\frac{4 \cdot \pi \cdot r^{3}\left(d-d_{0}\right) \mathrm{g}}{3}
$$

де $d, d_{0}$ - густина дисперсної фази та дисперсійного середовища;

$g$ - прискорення сили тяжіння.

За заданих умов частинка 3 радіусом $r$ під дією сталої сили $f_{2}$ рухається з прискоренням доти, поки не набере швидкості $U$, за якої $f 1=f 2$, після чого частинка рухається рівномірно. За умови рівноваги, після прирівнювання рівнянь (1.1) та (1.2) $(f 1=f 2)$ отримаємо рівняння для визначення радіуса частинок:

$$
r=\sqrt{\frac{9 \eta U}{2\left(d-d_{0}\right) \mathrm{g}}},
$$

де $\eta$-в язкість дисперсійного середовища;

Оскільки в язкість, густина середовища та густина порошку є сталими для даної системи, їх позначають через константу $K$ :

$$
K=\sqrt{\frac{9 \eta}{2\left(d-d_{0}\right) g}} .
$$

Отже, радіус частинок визначали із такого рівняння

$$
\mathrm{r}=\mathrm{K} \sqrt{U}
$$

3 рівняння (1.5) робимо висновок, що частинка в суспензії осідає зі сталою швидкістю, яка залежить від іiі радіусу.

Розрахунок розмірів частинок методом седиментаційного зважування зводиться до визначення швидкості осідання суспензії, тому замість лінійної швидкості осідання суспензії $\mathrm{U}=\mathrm{H} / \tau$ знаходили пропорційну їй масову швидкість осідання - приріст маси осаду з часом.

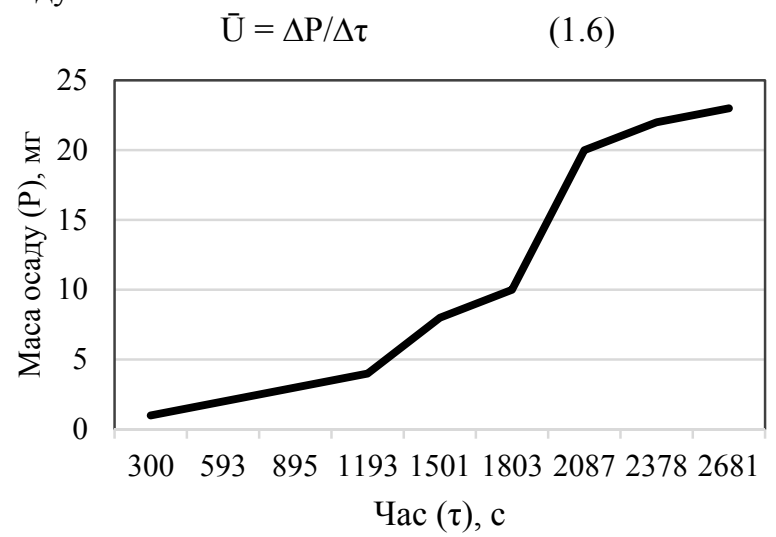

\section{Рис. 1. Крива седиментації напою з ядер волоського горіха}

Крива седиментації в координатах $\mathrm{P}=f(\tau)$ показує залежність маси осаду від тривалості осадження. Перші двадцять хвилин (1200 с) осадження відбувалось повільно з поступовим збільшенням маси осаду. Різке збільшення маси осаду спостерігається в період 20...35 хвилин осадження, що свідчить про підвищення швидкості осідання часточок у цей період. Пришвидшення осадження пояснюється зменшенням опору дисперсного середовища за рахунок відділення жирової фази напою. Починаючи з 35 хвилин (2100 с) осадження маса осаду стабілізувалась - це свідчить 
про повне осадження нерозчинних завислих в середовищі часточок.

Радіус r частинок визначали за рівнянням (1.5), для кожного показника часу відповідає свій радіус.

Величини фракцій $\mathrm{F}$ визначали у відсотках відношенням маси кожної 3 фракцій до загальної маси осаду. Дані розрахунків відображені у табл. 1.

За формулою (1.6) розраховували швидкість осідання, яка характеризує збільшення маси осаду за визначений час. Найбільша швидкість осідання спостерігалась в період 20...35 хвилин осадження $\left(\mathrm{U}_{5} \ldots \mathrm{U}_{8}\right)$.

Таблиия 1

Результати розрахунків радіусів частинок дисперсної фази та відсоткового вмісту фракцій

\begin{tabular}{|c|c|c|c|c|c|}
\hline № & $\mathrm{U}$ & $\mathrm{r}$, мкм & $\Delta \mathrm{r}$, мкм & $\mathrm{F}, \%$ & $\mathrm{~F} / \Delta \mathrm{r}$ \\
\hline 1 & 0,00333 & 0,02268 & - & 4,35 & - \\
\hline 2 & 0,00341 & 0,02295 & 0,00027 & 4,35 & 16111,11 \\
\hline 3 & 0,00331 & 0,02261 & 0,00034 & 4,35 & 12794,12 \\
\hline 4 & 0,00336 & 0,02278 & 0,00017 & 4,35 & 25588,24 \\
\hline 5 & 0,01299 & 0,04479 & 0,02201 & 17,38 & 789,64 \\
\hline 6 & 0,00662 & 0,03197 & 0,01282 & 8,70 & 678,63 \\
\hline 7 & 0,03521 & 0,07374 & 0,04177 & 43,47 & 1040,70 \\
\hline 8 & 0,00687 & 0,03257 & 0,04117 & 8,70 & 211,32 \\
\hline 9 & 0,00330 & 0,02257 & 0,01 & 4,35 & 435 \\
\hline
\end{tabular}

Радіус частинок $\mathrm{r}$ коливається в діапазоні 0,02257...0,04479 мкм, тому напій можна вважати дрібнодисперсним. Розрахунки відношення відсоткового вмісту фракції $\mathrm{F}$ до різниці радіусів часточок $\Delta \mathrm{r}$ свідчать, про те що найімовірніший розмір частинок $\mathrm{r}_{4}=0,02278$ мкм, він відповідає максимальному значенню фракції.

\section{Висновки}

Розробка рослинних напоїв з високим вмістом білку - перспективний напрямок розвитку харчової галузі. Білки рослинного походження що переходять у напій при екстрагуванні з часом осідають, що впливає на консистенцію напою. Тому визначення дисперсності напою було одним із основних завдань досліджень.

У результаті проведеного седиментаційного аналізу напою було побудовано криву седиментації, яка характеризує процес осадження за визначений період часу. Також за результатами виконаних досліджень було визначено розміри частинок дисперсної фази та швидкість їх осідання. Розміри частинок осаду напою коливались від 0,02257 мкм до 0,04479 мкм. Швидкість осідання тобто приріст маси осаду з часом становить $0,00330 \ldots 0,03521$ г/c.

Перспективи подальших досліджень. Майбутні дослідження включатимуть аналіз стабілізаторів харчових продуктів та визначення залежності швидкості осідання від виду та концентрації стабілізатора в напої. Також планується дослідження хімічного складу напою та визначення залежності основних показників якості від часу зберігання напою.

\section{Бібліографічні посилання}

Poperechnyj, A.M., Kornijchuk, V.G. (2009). Cinnist' gorihovoi' syrovyny ta peredumovy do procesiv i'i' pererobky. Obladnannja ta tehnologii' harchovyh vyrobnyctv Zbirnyk naukovyh prac'. 20, 46-49 (in Ukrainian).

Peshuk, L.V., Nosenko, T.T. (2011). Biohimija ta tehnologija olije-zhyrovoi' syrovyny. Navch. posib. K.: Centr uchbovoi' literatury (in Ukrainian).

Mank, V.V., Miroshnykov, O.M., Podobij, O.V., Stecenko, N.O. (2008). Koloi'na himija: Praktykum. K.:NUHT (in Ukrainian).

Mchedlov-Petrosjan, M.O., Lebid', V.I., Glazkova, O.M., Jel'cov, S.V., Dubyna, O.M., Panchenko, V.G. (2004). Osnovy koloi'dnoi' himii': fizyko-himija poverhnevyh javyshh i dyspersnyh system. H.: HNU (in Ukrainian).

Стаття надійшла до редакиії 17.09.2016 